\title{
Fenomén stereotype threat a jeho vliv na školní výkony*
}

\author{
Irena Smetáčková \\ Univerzita Karlova v Praze, Pedagogická fakulta
}

\begin{abstract}
Abstrakt: Článek představuje $v$ českém prostředí dosud málo známý koncept ohrožení stereotypem (stereotype threat), který začal být od poloviny 90 . let 20 . století užíván $\mathrm{k}$ vysvětlení toho, proč určité skupiny studujících dosahují nízkých vzdělávacích výsledků, a to především ve výkonově vymezených situacích. Jedná-li se o skupinu, vǔči níž ve společnosti existuje stereotyp, že pro danou oblast nemá vhodné schopnosti, a je-li před samotným výkonem stereotyp zdůrazněn, může dojít u osob vnímajících se jako součást stereotypně nahližené skupiny $\mathrm{k}$ inhibici jejich výkonů.
\end{abstract}

Kličová slova: ohrožení stereotypem (stereotype threat), nerovnosti ve vzdělávání, školní výkony, školní selhání

\section{Stereotype Threat: Impact on School Achievements}

Abstract: The article presents a concept of stereotype threat which is used from 90's for an explanation why certain groups of students achieve low educational results, mainly in high-stakes situations. If there exists the stereotype assuming that members of some group haven't abilities for a special field, and if this stereotype is emphasized just before the performance, then it leads to an achievement's inhibition of person who accounts his/herself as a member of this group. The concept of stereotype threat is quite unfamiliar in Czech scientific background.

Keywords: stereotype threat, inequalities in education, school achievements, school failure

\section{1 Úvod}

Tématem, které stojí tradičně v centru společného zájmu pedagogiky a psychologie, je školní selhávání1. V rámci pedagogické psychologie existují četné studie tohoto fenoménu, jejichž základním cílem je popsat z psychologického hlediska př́činy žákovských neúspěchů a eventuálně ověřit efektivní postupy vedoucí k jejich odstranění. Přístup dominující v české psychologii spočivá v uchopení vzdělávacích potiží prostřednictvím složení a míry individuálních dispozic, které mohou být ve vztahu k nárokům školy bud' nedostatečné, nebo v určitém ohledu se vymykající. Největší badatelský důraz se proto klade na intelektové schopnosti, volní vlastnosti, motivaci

* Článek vznikl v rámci projektu „Nerovné podmínky škol - nerovné šance žákư“ financovaného Grantovou agenturou CR (číslo projektu P407-11-1556).

1 Článek operuje se spojením „školní selháváni““ a ,školní neúspěšnost“. Ačkoliv mezi oběma jevy existují dílčí rozdíly, ze stylistických důvodů jsou v textu použivána jako synonymické označení pro stav opakovaných potíźi při plnění nárokủ stanovených školou. 
12 a postoje (např. Pavelková, 2002; Hř́bková, 2005). K těm se nejčastěji přistupuje jako $\mathrm{k}$ jedinečným pro každého žáka/yni, př́padně se hledají charakteristiky skupin žáků s podobným profilem $v$ dominantně sledované oblasti, které se kombinují s dalšími ryze psychologickými faktory (např. Fráňová \& Preiss, 2008). Zahraniční výzkumy (ve shodě s českými sociologicky orientovanými výzkumy) opakovaně potvrzují, že významný vliv na školní úspěšnost mají mimo jiné socio-ekonomicko-kulturní faktory, pomocí nichž lze vymezit různé skupiny žáků. Ty vykazují nenáhodnou vnitřní podobnost vzdělávacích výsledků a zároveň rozdílnost proti výsledkům ostatních skupin (např. Flick, 1998; Lareau, 2008; v ČR Katrňák, 2005; Hř́bková, 2005; Matějů, Straková \& Veselý, 2010).

Schematicky lze hlavní příčiny výkonových pravidelností u osob náležejících do shodné sociální skupiny spatřovat bud' $v$ jejich obdobných vrozených dispozicích, nebo $v$ sociokulturních podmínkách, jimž jsou společně vystaveny. Aktuální teorie považují druhý jmenovaný zdroj za významnější (Štech, 2000; Průcha, 2004); ovšem neshodují se $v$ tom, které charakteristiky skupiny související s jejím společenským postavením mají nejsilnější vliv a jak se tento vliv realizuje. Česká odborná diskuse sice odráží existenci různých př́stupů $\mathrm{k}$ interpretaci rozdílných školních výsledků odlišných žákovských skupin (a z toho hlediska je srovnatelná se zahraniční diskusí), ale otázka vztahu mezi sociokulturními a psychickými faktory² při selhání ve výkonových situacích $v$ ní téměř absentuje.

Česká psychologie nevěnuje hlubší systematickou pozornost demografickým a sociokulturním charakteristikám školně neúspěšných dětí (např. socioekonomickokulturní status, etnický původ či genderová př́slušnost). Je-li jim pozornost přeci jen věnována, pak spíše jako kontextuální, nikoliv explanační proměnné (např. Kulhánková \& Málková, 2008); a pokud jako explanační, pak spiše stabilní, determinující samotné dispozice (např. Madarasová-Gecková et al., 2008), nikoliv jako proměnné, která má svoji dynamiku a bezprostředně ovlivňuje psychické funkce $v$ konkrétních situacích. Práce, které by hlouběji využívaly také situační dynamické pojetí, jsou na českém psychologickém poli ojedinělé (např. psychologicky inspirovaný etnografický výzkum Bittnerová, Doubek \& Levínská, 2012).

Dominantně rozvíjené psychologické přístupy ke studiu školní neúspěšnosti jsou velmi inspirativní a pro poznání přičin žákovských selhání přínosné. Nicméně větší zájem o sociokulturní a demografické faktory na jedné straně a situační vlivy v kombinaci s širším kulturním zázemím na straně druhé by mohl doplnit a prohloubit dosavadní pedagogicko-psychologické zkoumání toho, jakými mechanismy vzniká u jednotlivých členů skupiny podobný výkon. Tento článek se proto věnuje představení konkrétního psychologického konceptu ohrožení stereotypem neboli stereotype threat (Steele \& Aronson, 1995), který patřil v zahraničí během uplynulých patnácti letech k nejvíce diskutovaným. Jeho relevance pro českou odbornou diskusi vyplývá

2 Ačkoliv by to bylo užitečné pro komplexnější argumentaci fenoménu stereotype threat, tento text bohužel neposkytuje prostor pro zasazení vazby mezi kulturními a psychickými strukturami do kontextu kulturní psychologie rozvíjené v tradici L. Vygotského. 
i z aktuálních témat českého školství, jako je plošné testování v rámci maturitní zkoušky či na základních školách, při jejichž výzkumu by mohl nabídnout vhodné dílčí výkladové schéma.

\section{Typologie př̀ičin školního selhání}

Modelů vysvětlujících sklony určitých sociálních skupin ke školní neúspěšnosti existuje velké množství. Pro účely tohoto textu navrhuji jejich členění do tří množin podle hlavní příčiny selhání, která nastupuje $v$ různých fázích vzdělávacího procesu od obecnějšího nastavení vůči školním úkolům, přes budování a využivání jednotlivých schopností podmiňujících úspěch ve školních úkolech, po postup v konkrétních výkonových situacích. ${ }^{3}$

První vyčleněná množina modelů operuje se vztahem dětí ke škole a školnímu vzdělávání, který je budován v rodině. Předpokládá se, že mezi žáky/kyněmi ze skupin, které dosahují slabých výkonů, převládá odstup od školního angažmá. Proto nemůže dojít k plnému uplatnění jejich potenciálu, což se projeví ve slabších výsledcích. Z hlediska přesnějšího určení zdroje školního postoje je množina vnitřně heterogenní - část modelů zdůrazňuje absenci školního úspěchu mezi rodinnými a následně žákovskými hodnotami (např. Willis, 1977), zatímco dalši část spatřuje př́činu $v$ nedostatečném porozumění instituci školy a jejím pravidlům (např. Ogbu, 1992). V prvním př́padě je okamžitým důsledkem slabá proškolní motivace, která dítěti brání, aby využívalo naplno své schopnosti, a rodičům, aby dítěti asistovali $\checkmark$ přípravě na školu. $V$ druhém př́padě je existující motivace kombinována s pocitem cizosti a nesrozumitelnosti školy, který při opakovaných dílčích neúspěších vede k rezignaci a druhotnému snížení proškolní motivace.

Společným jmenovatelem této množiny modelů je zájem o celkovou společenskou konstelaci mezi institucí školy a institucí rodiny a z ní vyplývající nastavení školní socializace a její kompatability se socializací rodinou (Singly, 1999; Laerau, 2000 aj.). Nosnými koncepty spadajícími do této skupiny modelů jsou zejména kulturní kapitál (Bourdieu, 1998), jazykový a kulturní kód (Bernstein, 1977) či strukturace rodiny (Kohn, 1977). Ty upozorňují na vazbu mezi dvěma oblastmi - na jedné straně jde o socio-ekonomicko-kulturní status rodiny a s tím související typický životní styl, na druhé straně o postoj ke vzdělání, porozumění škole a určité dovednosti (např. sociální cit), které vytváří širokou základnu pro potenciální školní ne/úspěšnost. Jinými slovy, s kulturními habity rodiny, které korespondují s jejím umístěním na společenském žebřičku, souvisí určitá motivace získat vzdělání a míra i struktura nespecifických schopností, jež jsou k tomu nutné.

3 Příčiny školní neúspěšnosti určitých žákovských skupin lze samozřejmě třídit i podle jiných kritérií, např. podle míry vrozenosti, podle zodpovědnosti socializačních institucí, podle hloubky vzdělávacích nerovností, které v jejich důsledku vznikají atd. Alternativní třídění sociokulturních zdrojů školního neúspěchu nabízejí v českém kontextu zejména práce S. Štecha (např. 2000), D. Gregera (např. 2010), P. Matějů, J. Strakové a A. Veselého (2010) či N. Simonové a T. Katrňáka (2008) a dalších. 
Oborovým těžištěm těchto modelů je především sociologie, která sleduje makrosociální vztahy mezi rodinným pưvodem a vzdělávacími výsledky a na základě nalezených korelací usuzuje na existenci zprostředkujících proměnných, které jsou dominantně popisovány jako jevy kulturní (nikoliv úzce psychické) povahy. Psychologické stránky rozvoje schopností uplatnitelných ve školním vzdělávání a budování postojů ke škole $v$ prostředí rodinné a následně školní socializace stojí spiše v pozadí. Jednu z mála takových teorií reprezentuje Blau-Duncanův sociálně-psychologický model, který kombinuje sociologický a psychologický př́stup (Blau \& Duncan, 1967), či již zmíněná povaha rodinné kultury $v$ teorii $M$. Kohna (1977) a později A. Lareau (1992). Ačkoliv je první skupina modelů velmi inspirativní, za její nedostatek můžeme považovat jednak přehlížení konkrétních mechanismů a postupů, kterými se schopnosti a postoje determinující následnou školní úspěšnost vytváří, a jednak popisování existujících statistických trendů bez pochopení odchylek od něj (Štech, 2000; Průcha, 2004; Greger, 2010).

Druhá množina modelů vysvětlující školní selhání volně navazuje na výše představenou první skupinu modelů, avšak pozornost hlouběji zaměřuje na konkrétní individuální schopnosti žáků/yň. Na rozdíl od předcházejících výkladů, které se věnovaly obecné připravenosti, porozumění a postojům vưči škole (tedy nespecifickým charakteristikám), jsou zde studovány specifické charakteristiky bezprostředně využitelné při plnění konkrétních školních úkolů. Tím se míní jednak míra a složení aktualizovaných intelektových, volních a temperamentových dispozic a jednak dílčí znalosti a dovednosti, jež si dítě osvojuje $v$ rámci rodinné socializace a které následně vedou k zefektivnění školního učení a katalyzují školní socializaci. ${ }^{4}$ Jednotlivé modely variují $v$ tom, zda důvod selhání spatřují spíše $v$ oblasti individuálních dispozic, nebo v oblasti znalostí a dovedností, eventuálně v jejich kombinaci. Každá z těchto oblastí přitom implicitně předpokládá určitou míru ovlivnitelnosti sociálními stimuly. Některé dílčí modely operují s vysokou mírou vrozenosti schopností v daných skupinách, zvláště v př́padě inteligence (např. Herrnstein \& Murray, 1994). To vede ke stanovisku, že školní selhání dětí pocházejících z daných skupin je téměř zákonité. Naopak v modelech $\mathrm{s}$ vyšším vlivem sociálních faktorů se otevírá prostor pro úvahy o změně širokých sociálních struktur, která by následně umožňovala zvýšení šancí na školní úspěch (Greger, 2010; Simonová \& Katrňák, 2008). Nejsilněji je tato skupina modelů ukotvena $v$ sociologii a částečně (zejména $v$ př́padě modelů, které operují s individuálními dispozicemi) v psychologii.

Třetí množina modelů vysvětluje selhání v dílčích výkonových situacích, jako je školní zkoušení či řešení externě zadávaného testu. Tyto modely řeší otázku, proč ve výkonových situacích (a často právě jen v těchto situacích) děti nedokážou využít své schopnosti a v úkolu neuspějí. Často uplatňovanými koncepty jsou sociální inhibice (Zajonc, 1965), self-efficacy neboli vlastní účinnost (Bandura, 1997) či ohrožení stereotypem (Steele, 1997). Na rozdíl od dvou předchozích množin modelů, které se zabývají celkovým nastavením předcházejícím konkrétním výkonovým situacím, se

4 Příkladem specifické výbavy na začátku školní docházky může být podrobné rozlišování barevného spektra, včetně adekvátních označení, či znalost lidových písniček a ř́kadel. 
zde pozornost klade na aktivaci a průběh psychických mechanismů v závislosti na situačním kontextu. Určitý repertoár vzorců chování ve výkonových situacích je v člověku „před-připraven“ na základě jeho dispozic a biografických zkušeností. Následně v konkrétní situaci dojde $\mathrm{k}$ uplatnění některého $\mathrm{z}$ nich, a to $v$ důsledku toho, jak si jedinec situaci interpretuje. Oborové zázemí této skupiny modelů tvoří především psychologie. Jak je z popisu zřejmé, identifikované tři tradice výkladu žákovských selhání nepojednávají o disparátních, vzájemně nezávislých příčinách, nýbrž o faktorech, které se vztahují k odlišným rovinám či fázím procesu školní neúspěšnosti, a proto se mohou vzájemně prolínat: selhání v aktuální výkonové situaci vyrůstá z celkového postoje vưči škole a z dosažené úrovně schopností; zároveň opakované selhávání negativně působí na rozvoj a posuzování vlastních schopností a na postoj ke školním úkolům. Školní neúspěšnost se tak odehrává v uzavřeném kruhu, jehož jedním článkem jsou situační propady (vedle obecného postoje ke škole, dispozic, znalostí a dovedností). $\mathrm{V}$ perspektivě opakovaných selhání se neúspěch $\mathrm{v}$ jednotlivé situaci může jevit méně podstatný až neviditelný. Ovšem ve skutečnosti jde o článek zásadního významu, protože situační selhání mưže tvořit v dlouhodobém horizontu scénář neúspěšného žáka a zároveň posilovat stereotypní představu, že děti spadající do určité sociodemograficky vymezené skupiny nutně dosahují slabších výsledků. Je proto důležité porozumět tomu, jak selhání v konkrétní situaci vzniká, a na základě toho pak uvažovat o opatřeních, která naruší začarovaný kruh školní neúspěšnosti. Klíčovým, ale přitom v českém kontextu málo známým vysvětlením aktuálního selhání v konkrétní situaci je efekt ohrožení stereotypem.

\section{Koncept „ohrožení stereotypem“}

Koncept „stereotype threat“ byl do sociálních věd zaveden v roce 1995, kdy američtí sociální psychologové C. M. Steele a J. Aronson publikovali základní článek v časopise Journal of Personality and Social Psychology. V něm rozpracovali hypotézu zveřejněnou již o 30 let dřive autorským týmem vedeným I. Katzem (1965). Claude Steele ověřil a rozšíril její platnost na základě výsledků svých tří studií porovnávajících výsledky bílých a afroamerických studentů v národních didaktických testech $\mathrm{SAT}^{5}$, v nichž afroameričtí studenti a studentky dlouhodobě dosahovali výrazně slabších výkonů. Experimenty prokázaly, že jejich výkon klesá zejména v situacích, kdy jim bylo předem naznačeno, že je od nich očekáván nižší výsledek na základě rozšíreného stereotypu, že intelektové schopnosti Afroameričanů zaostávají za schopnostmi majority.

Článek vyvolal silnou odezvu, takže se koncept stereotype threat stal na poli psychologických přístupů k rozdílům ve školních výkonech jedním z nejvíce diskutovaných. Svědčí o tom mimo jiné následující údaje: v elektronické databázi psychologických časopisů EBSCO PsychInfo (Academic Search Complete) figuruje od roku 1995

Jak ukazuje kapitola 3.5, právě tato okolnost (tj. zúžení podnětového materiálu na testy) se stala jedním z hlavních důvodů, proč byl koncept stereotype threat kritizován. 
16 do současnosti 180 článků, které mají stereotype threat přímo v názvu, tj. explicitně se jím zabývají. Vyhledávač Google při zadání hesla stereotype threat vygeneruje téměř 6 milionů odkazů a pokud dojde ke zpřesnění přidáním hesla psychologie, klesne počet odkazů na necelé 4 miliony. ${ }^{6}$

Koncept stereotype threat může být do češtiny přeložen jako ohrožení stereotypem nebo hrozba stereotypu. ${ }^{7}$ Jak název napovídá, podstatou tohoto fenoménu je, že pod vlivem stereotypu dojde k momentálnímu nepř́iznivému ovlivnění činnosti člověka ve výkonově definované situaci tak, že jeho výsledky jsou pod úrovní jeho možností. Základním předpokladem je, že ve společnosti se vyznává negativní stereotyp o určité skupině a že konkrétní jedinec, jehož výkon je sledován, si existenci tohoto stereotypu uvědomuje. Slovy samotných autorů: „Existence takového stereotypu znamená, že jakýkoliv projev či charakteristika člověka, které se shodují s obsahem stereotypu, činí pro člověka stereotyp pravděpodobnějším popisem sebe sama z pohledu druhých a dokonce i z vlastního pohledu“ (Steele \& Aronson, 1995, s. 797). To tedy znamená, že koncept „se týká rizika přijetí negativního stereotypu o skupině jako vlastní charakteristiky“ (ibid., s. 797).

\subsection{Vztah mezi jedincem a stereotypem}

V psychologické terminologii představuje stereotyp široce sdílenou mentální strukturu, která zahrnuje soubor charakteristik vystihujících určitou kategorii lidí, přičemž alespoň jedna z nich je kategoriální informací (Schneider, 2004). Tou bývá snadno rozlišitelný znak, na základě něhož lze jedince přiřadit ke skupině, jejiž charakteristiky jsou pak na něj automaticky přeneseny. $V$ tomto smyslu je stereotyp „přesvědčení, že jsou sociální kategorie K asociovány s atributy A1, ..., An. Tyto atributy nejsou definičními znaky kategorie, tj. nejsou s kategorií asociovány logicky“ (Hnilica, 2010, s. 13). Stereotypy vznikají na základě zkušeností (at’ př́mých, nebo zprostředkovaných), z čehož vyplývá, že jsou pamět’ovými schématy, která obsahují informace o atributech dané kategorie a o jejich vzájemných vztazích, a která umožňují rychlé zpracování a uložení informací (Hnilica, 2010). Základním procesem je generalizace a zřetězení, po jejichž aplikaci jsou od představitelů daných kategorií očekávány charakteristiky, které nemají empirickou oporu v jejich behaviorálních projevech. Stereotypizace je tedy specifickým př́padem kategorizace coby základního principu sociální percepce a kognice (Schneider, 2004). S její pomocí člověk získává orientaci v sociální realitě, aniž by musel poznávat a zpracovávat všechny dílči informace (Flick, 1998). Toto pozitivum je ovšem vykoupeno rizikem neúplného a zkresleného poznání druhých a vlastního potenciálního znevýhodnění v případě,

6 V tomto světle se může zdát překvapující, že česká psychologická odborná periodika obsahují jen jeden článek, který o něm částečně pojednává a uvádí jej mezi svými kličovými slovy (Franěk, 2009).

7 Tento překlad uživá A. Zelová (in Výrost \& Slaměník, 2008). Z terminologického hlediska však považuji za vhodnější překlad ohrožení stereotypem, nebot' je tím přesněji vystižena podstata fenoménu - pozornost je obrácena $k$ jedinci, jehož výkon je ovlivněn (ohrožen) existencí stereotypu. 
že je člověk sám nahližen svým okolím (například vyučujícími) prostřednictvím stereotypů a předsudků. ${ }^{8}$

Vzhledem $\mathrm{k}$ tomu, že je stereotyp primárně schématem skupiny a že každý člověk sám sebe vnímá mimo jiné jako člena skupiny, tvoří stereotypy důležitou platformu pro ustavování sociální identity člověka. Ta spočivá $v$ přináležitosti $\mathrm{k}$ určité skupině (bez ohledu na to, zda je do ní člověk přiřazován druhými, či se k ní sám dobrovolně připojuje ${ }^{9}$ ), a v kritickém vymezení vưči skupinám jiným (Flick, 1998). Jako součást obrany vlastního já mají lidé tendenci hodnotit skupiny, do nichž náleží, jako významnější než skupiny cizí, a zároveň mají tendenci patřit do skupin, které považují za hodnotnější (Schneider, 2004). Využívají k tomu jednak stereotypy existující obecně ve společnosti, př́padně si vytvářejí v rámci vlastní skupiny určité dílči stereotypy týkající se vlastní skupiny (tzv. auto-stereotypy) či cizí skupiny (tzv. hetero-stereotypy).

Pokud lidé náleží do skupiny, vưči niž panují negativní stereotypy, zažívají často nelibost, která snižuje jejich afektivní přináležitost $k$ této skupině. To může vyústit ve dva důsledky - v odstup od skupiny, a/nebo ve snižení kladného sebepojetí. Sebepojetí je ohroženo zvláště v př́ipadě skupin vázaných na neměnné znaky (tzv. vrozený sociální status), kde nelze skupinu vlastním rozhodnutím opustit. Jiným vyústěním nutného členství $v$ určité skupině ovšem může být, že si skupina začne vytvářet alternativní auto-stereotypy, které původní nevýhodu transformují v přednost (srov. Willis, 1977), nebo přistoupí k tzv. sebe-znevýhodňování, jež představuje skupinový atribuční styl zmírňující dopad neúspěchu (Jones, 1990).

Pokud aplikujeme tyto mechanismy do školního prostředí, setkáváme se především s následujícími scénáři: dítě, kterému vyučující a spolužáci opakovaně zdůrazňují, že je součástí skupiny, vưči niž panují negativní stereotypy týkající se potenciálu pro školní úspěšnost (např. v USA Afroameričané či dívky v technických doménách, v ČR zřejmě Romové), zažívá bud' nedůvěru ve vlastní schopnosti, a/nebo odstup od školní třídy složené z majority, či odstup od vlastní skupiny. To mǔže vyústit ve snižení efektivity učení $v$ žákovském kolektivu a zároveň $v$ omezení učebního úsilí i využivání potenciálu v konkrétních výkonových situacích.

Výše popsané účinky nastávají v důsledku toho, že stereotypy jako mentální kategorie obsahují silnou hodnotící složku (vedle kognitivní složky). V tomto smyslu jsou stereotypy specifickým typem postojů, a jako takové zahrnují informační, afektivní a konativní elementy (Schneider, 2004). Z toho plyne, že lze stereotypy dělit na pozitivní a negativní v závislosti na tom, zda jsou charakteristiky spojované s danou skupinou ve společnosti (eventuálně samotným jedincem či členy př́slušných skupin) oceňovány. Jak již bylo naznačeno, pozitivní stereotypy posilují tendenci považovat skupinu za referenční neboli vztažnou, zatímco negativní stereotypy naopak častěji

8 Vztahem mezi stereotypy a předsudky se zde nebudeme zabývat, nebot' to překračuje zaměření tohoto článku. Navzdory řadě odlišností je společným jmenovatelem stereotypů a předsudků apriorně existující a generalizovaná, a tudíž nepřesná, představa o jedinci.

9 Psychologický aspekt tohoto rozdílu vystupuje na př́kladu etnicity, která je tělesně zřetelná (jiná barva pleti), a naopak nezřetelná. Zatímco s první se jedinec vyrovnávat musí, protože jej okolí s jeho odlišností konfrontuje, s druhou se vyrovnávat může, pokud si ji zvolí jako svůj referenční rámec. 
18 vedou k odmítání skupiny a svého členství v ní. Z toho vyrůstá požadavek, aby alespoň škola (pokud to nelze $v$ celé společnosti) důsledně trvala na odstraňování stereotypních představ o školní ne/úspěšnosti některých skupin žáků. Žák/yně náležející ke skupině, která je považována za problematickou či nehodnotnou, nesaturuje svoji sociální identitu a nezažívá stav takové psychické pohody, aby mohl být naplno využíván jeho/její kognitivní potenciál. Právě toto tvoří základní mechanismus fenoménu ohrožení stereotypem.

\subsection{Mechanismus ohrožení stereotypem}

Fenomén ohrožení stereotypem nastává v situacích, kdy je jedinec vystaven působení stereotypního přesvědčení, podle něhož by jako člen určité skupiny měl dosáhnout slabého výkonu. Jeho výsledky pak jsou skutečně inhibovány v porovnání s jeho potenciálem a s jeho výsledky v situacích, kdy není vystaven stereotypu o slabém výkonu (Steele \& Aronson, 1995). Předpokládá se, že jedinec má rozvinuté schopnosti pro dosažení výrazně vyššího výkonu a že jej za jiných okolností také dosahuje. To znamená, že není zásadně narušena identifikace člověka s danou výkonovou oblastí ve smyslu, že je pro něj osobně důležité dosáhnout úspěchu (či se alespoň vyhnout neúspěchu) a vynakládá na to úsilí (Steele, 1997).

Kromě popsaného situačního vlivu mohou stereotypy působit i v delším časovém horizontu. $\mathrm{V}$ takovém př́padě je jedinec dlouhodobě konfrontován se stereotypním přesvědčením, že skupina, do níž patří, nemá dispozice nutné pro dobré výkony v určité oblasti. Týká se to např́klad etnického stereotypu, že Afroameričané či Hispánci mají nižší intelektové schopnosti, nebo genderového stereotypu, podle něhož ženy neovládají matematiku. Při opakované expozici takovému stereotypu může nastat tzv. disidentifikace, která představuje „rekonceptualizaci Já a vlastních hodnot tak, aby došlo $\mathrm{k}$ vyjmutí dané oblasti z osobní identity, takže netvoří základ pro sebehodnoceni“ (Steele, 1997, s. 614). Výsledkem je, že člověk nepovažuje konkrétní doménu (např. obecně školní výkony či konkrétní předměty jako je matematika) za referenční, a proto jej nebudou př́padné neúspěchy identitně ohrožovat. Zároveň to však s sebou přináší celkové snížení motivace pro danou oblast a pokles aktivit rozvíjejících schopnosti, které by mohly vést $k$ úspěšnému výkonu. Výkonnost jedince $v$ dané oblasti je tedy celkově nízká, ovšem nevykazuje výkyvy a krátkodobé podhodnocení potenciálu. ${ }^{10}$ Ačkoliv v raných publikacích bývá i tento typ vlivu stereotypů podřazován pod koncept ohrožení stereotypem (Aronson \& Steele, 1995), aktuálně panuje shoda, že ohrožení stereotypem představuje ryze situační fenomén, kdy při momentální expozici stereotypu dojde ke zhoršení tradičně dobrých výkonů (Schneider, 2004; Doan, 2008).

Bližší vhled do mechanismu výkonového selhání lze získat na základě experimentálních studií, prostřednictvím kterých byl efekt ohrožení stereotypem definován

10 Nespecifický potenciál člověka sice může být reálně vy̌̌ší, ale kvůli nedostatečné motivaci a stimulaci nedošlo $k$ jeho rozvinutí. Na základě běžných projevů lze nenaplněný potenciál jen obtížně identifikovat. 
(Steele \& Aronson, 1995; Steele, 1997; Doan, 2008). Původní americká studie porovnávala výsledky 114 bílých a afroamerických vysokoškolských studujících v didaktickém testu, který vycházel z národních srovnávacích zkoušek SAT. Respondenti/ ky byli rovnoměrně rozděleni do tři skupin, z nichž každé byl zadán test, ovšem s odlišnými doprovodnými informacemi. Jedné skupině bylo řečeno, že cílem didaktického testu je diagnostikovat jejich intelektuální schopnosti, což mělo navodit stav ohrožení stereotypem, podle něhož Afroameričané mají nižší dispozice pro akademický výkon. U dalších dvou skupin nebyl stereotyp aktivován $-\mathrm{v}$ jednom př́padě byl test představen jako anonymní součást výzkumu řešení problémů, bez vazby na individuální výkon, $v$ druhém př́padě bylo řečeno, že výsledky $v$ testu budou známy jen zkoumaným osobám, pro něž může být obtížnost testu výzvou pro zmapování vlastních schopností. Test tvořilo 30 položek vybraných z verbálního subtestu národních zkoušek Graduate Record Examination, které byly značně obtižné (u 27 z nich byla průměrná úspěšnost nižší než 30 \%). Kromě testu všechny osoby vyplňovaly dalších pět dotazníků, které byly zaměřeny na následující oblasti: (a) popis vlastních akademických kompetencí, (b) hodnocení faktorů interferujících do řešení testu, (c) odhad obtižnosti testu, (d) odhad vlastní úspěšnosti v testových položkách, (e) vysouzení účelu testu.

Analýzy ukázaly, že ve skupině, která řešila test jako diagnostický, a v níž tedy byl nejsilněji aktivován stereotyp o nižších intelektových schopnostech Afroameričanů, dosáhli bílí studenti/ky lepších výsledků. Rozdíl ve výkonech byl silně statisticky významný při porovnání první a druhé skupiny, tj. při řešení testu za explicitně diagnostických a explicitně nediagnostických podmínek. $V$ prípadě třetí skupiny, které byl test zadán jako výkonový, ale v nediagnostických podmínkách (tj. jako výzva pro zjištění úrovně vlastních schopností, ovšem bez prezentace výsledku ostatním), byly výkony afroamerických studujících navzdory očekávání slabší oproti výsledkům majority. Rozdíly mezi bělošskými a afroamerickými studujícími v první a druhé skupině se ukázaly rovněž $v$ doplňkových testech. Odlišné výsledky třetí skupiny ovšem naznačovaly, že klíčovým faktorem není samotná explicitní př́tomnost stereotypu, nýbrž subjektivní interpretace situace ${ }^{11}$ (tj. na tom, zda a jak si jedinci stereotyp zvýznamňují). $Z$ ní pak vyrůstají pocity úzkosti ${ }^{12}$ a/nebo rušivé myšlenky $v$ průběhu řešení úkolu, které jsou již konkrétními důvody snížení výkonu. Za účelem ověření těchto hypotéz realizovali $C$. Steele a J. Aronson další tři experimentální studie, $\checkmark$ nichž postupně prokázali jejich platnost. Základní série experimentů dospěla k závěrům, že u afroamerických studujících nastává snižení výkonů v situaci, kdy považují úkol za obtižný, a to na základě informace od zadavatelů či na základě vlastního vyhodnocení. Následkem toho u nich dochází k silnější kognitivní aktivaci

11 V dané studii se úkoly týkaly základního lexikálního zpracování informací a dále vyšších usuzovacích procesů. Úkoly na lexikální zpracování spočívaly v doplňování chybějících písmen do slov, která souvisejí se stereotypy (např. - - ce, po doplnění „race“). Z druhu a rychlosti doplnění se usuzovalo na míru kognitivní aktivace stereotypu.

12 Nástrojem byl standardizovaný dotazník měřící úzkost - Spielberger State Anxiety Inventory, který všichni respondenti/ky vyplňovali ihned po vyřešení didaktického testu. 
20 stereotypu, hlubším pochybnostem o svých schopnostech, větším obavám o výsledek a vyšší motivaci oddělit sebe od stereotypizované skupiny.

\subsection{Př́činy inhibice výkonu}

Podle M. Steeleho (1997) probíhá snižení výkonů pod vlivem momentálně působícího stereotypu čtyřmi základními způsoby. První představuje př́liš silné nabuzení, které redukuje využitelné schopnosti. Autora typologie mưžeme doplnit, že se jedná o specifickou aplikaci aktivační teorie motivace, podle níž pro optimální výkon je třeba dosáhnout adekvátní - tedy ne př́liš vysoké, ani př́liš nízké aktivace organismu (Thayer, 1978; Pavelková, 2002). Druhý způsob inhibice výkonů souvisí s rozpaky či ostychem, které vyvolá deklarace nízkého očekávání v protikladu k představě samotného člověka, že by mohl uspět. Pocity ambivalence a nejistoty vedou $\mathrm{k}$ redukci soustředění a úsilí věnovaného samotnému úkolu. Třetí forma snižení výkonů spočívá $\checkmark$ akceptaci představy, že jedinec není schopen dosáhnout dobrého výsledku. Tím se přinejmenším vytvoři obava z neúspěchu, která limituje úspěšné řešení, nebo dokonce dojde $\mathrm{k}$ přijetí scénáře neúspěchu. Čtvrtým důvodem omezení výkonu může být nadměrná opatrnost, která vyplývá ze snahy uspět a prokázat osobní či celkovou neplatnost stereotypu. Na rozdíl od předchozího důvodu, který představuje pokles úsilí, protože člověk řešení úkolu vzdává, v tomto prípadě nastává jeho přemíra vedená potřebou dokázat, že stereotypní očekávání nejsou správná (Steele \& Aronson, 1995; Steele, 1997).

Jednotlivé aspekty představené typologie byly rozpracovány velkým množstvím dílčích studií, které prokázaly, že za inhibicí výkonnosti mưže stát úzkost, rozptýlení, ztráta motivace, očekávání nízkého výkonu, zúžení pozornosti, redukce kreativity, redukce sebekontroly, fyziologický stres, pokles úsilí nebo naopak jeho přemíra (Doan, 2008).

Americká psycholožka Toni Schmader a její kolegové představili v roce 2008 integrovaný model ohrožení stereotypem, který definuje tři nejsilněji působící faktory a ukazuje jejich místo ve vztahu mezi stereotypem a výkonem. Podle tohoto modelu se u člověka, který je identifikován jednak s oblastí výkonu a jednak se skupinou, vưči niž je stereotyp namířen, při konfrontaci se stereotypním očekáváním rozvíjí následující tř̌ stavy/procesy. Prvním je fyziologický stres. Bylo zjištěno, že u lidí vystavených stereotypům došlo $\mathrm{k}$ poklesu tepové frekvence, ke zvýšení krevního tlaku, k poklesu teploty a zvýšení vodivosti kủže (Osborne, 2007). Druhým faktorem je soustředění na samotnou aktivitu spojenou s úkolem, což vede $k$ zúžení pozornosti a omezení kreativity. Ve snaze mít svoji činnost pod maximální kontrolou pak člověk snadno přehlédne některé prvky významné pro úspěšné řešení úkolu. Třetím faktorem je emocionální regulace, respektive tendence ř́dit své afektivní reakce na vzniklý stav ohrožení. Expozice stereotypům u člověka obvykle vyvolává nepř́jemné myšlenky a pocity, které se nejvíce týkají možnosti vlastního selhání. Člověk se snaží od těchto myšlenek a pocitů oprostit, tj. dostat své rozpoložení pod kontrolu. Po- 
kud tato kontrola selhává, dochází k akceptaci neúspěchu; pokud kontrola funguje, vyžaduje investici značného úsilí, které následně chybí v samotném řešení úkolu.

První vlna výzkumů mapující mechanismy ohrožení stereotypem se zaměřovala především na afektivní aspekty jako je obava ze selhání, zatímco stávající výzkumy více studují kognitivní aspekty. Jak předpokládají ve svém integrovaném modelu Schmader, Johns a Forbes (2008), kritickým článkem ve vazbě mezi fází konfrontace se stereotypem a fází inhibice výkonu je pracovní pamět'. Jedná se o krátkodobou pamět', která představuje vědomou a aktivní část pamět'ového systému a jako taková je zapojena do procesu zpracování relevantních informací v probíhajících úkolech. Každý z výše popsaných tří faktorů - fyziologický stres, zúžení pozornosti, afektivní regulace - přispívá svým jedinečným způsobem k omezení funkce pracovní paměti. Není-li pracovní pamět' plně funkční, jedinec má ztíženo či zpomaleno porozumění úkolu a nalezení jeho řešení (Osborn, 2007; Schmader \& Johns, 2003). Jedna ze studií, která to prokázala, srovnávala rozsah pracovní paměti u dvou skupin dívek, z nichž jedna byla vystavena stereotypu, že ženy nemají nadání na matematiku. Pracovní pamět' byla operacionalizována jako schopnost vybavit si slova, která jim byla $v$ rámci úkolu zadána $\mathrm{k}$ zapamatování a která byla nutná pro úspěšné zvládnutí matematického úkolu. Skupina dívek, které nebyly vystaveny genderovému stereotypu, vykazovala výrazně větší rozsah své pracovní paměti (Schmader \& Johns, 2003).

\subsection{Důsledky ohrožení stereotypem}

Ohrožení stereotypem má řadu důsledků. Tím hlavním je krátkodobé zhoršení výkonu pod úroveň možností daného člověka. Jak jsme opakovaně zdůrazňovali, aby $k$ tomuto efektu došlo, musí být ve společnosti sdílen stereotyp, který předpokládá, že určitá skupina nemá vhodné dispozice pro úspěšné zvládání některé oblasti, a před výkonem je tento stereotyp zdůrazněn. Laboratorní studie i reálné školní podmínky ukázaly, že pokles výkonu nastává v prrípadě různých výkonových oblastí, k nimž se vztahují určitá stereotypní očekávání. Nejvíce studií se týkalo akademických výkonů v souvislosti s etnickými a genderovými stereotypy. ${ }^{13}$ Prokázalo se, že afroameričtí studující na všech stupních škol dosahují horších výsledků ve všech školních předmětech po zdůraznění stereotypního očekávání, podle něhož mají pro studium horší předpoklady než bělošští studující (Doan, 2008; Gallagher \& Kaufman 2004). Zároveň se ověřilo, že dívky vykazují horší výsledky v matematice po deklaraci stereotypního očekávání, že „holky nemají na tento předmět buňky“ (Keller, 2007). Ohrožení stereotypem ovšem nastává i mimo oblast akademických výkonů - například ženy dosahují nižších výsledků v atletice či v řízení auta, muži v péči o děti, starší osoby $\checkmark$ pamětních úkolech atd. (Osborne, 2007).

Při opakovaném působení efektu ohrožení stereotypem se vedle regrese výkonů dostavují i další důsledky. Častá bývá tendence připisovat příčiny neúspěchu vnitřním

13 Uvedené výzkumy jsou platné pro americkou populaci mladších generací. Protože inhibice výkonu plně závisí na relevanci stereotypu, nelze výzkumné nálezy přenášet do jiných kulturních prostředí, kde není existence daných stereotypů prokázána. 
22 dispozicím, kdy jedinec pocit’uje vưči úkolovým nárokům vlastní nedostatečnost. Jestliže je expozice stereotypům dlouhodobá, může interní atribuce neúspěchu vyústit $v$ tzv. disidentifikaci, která představuje ztrátu zájmu o celou oblast, v níž se daný výkon realizuje. Rezignace na určitou výkonovou oblast v důsledku dlouhodobého vystavení stereotypům je symptomem jiných fenoménů než ohrožení stereotypem. Za nejbližší považuji koncept sebesplňujícího proroctví (Merton, 1968), koncept self-efficacy neboli vlastní účinnosti (Bandura, 1977) a koncept naučené bezmocnosti (Seligman, 1975).

Z atribučního hlediska opačnou tendencí je sebe-znevýhodňování (self-handicaping), které představuje defenzivní strategii vưči selhání ve výkonových úkolech (Jones, 1990). Jedinec aktivně buduje překážky bránící jeho úspěchu, aby tyto překážky $v$ př́padě reálného selhání mohl označit za důvod slabého výkonu (Steele \& Aronson, 1995). Přičina neúspěchu nespočívá v dispozicích, nýbrž v situačních faktorech. Jedná se tedy o preventivní omluvu neúspěchu, která však reálně vede k inhibici výkonnosti. K sebe-znevýhodňování lze využívat různé nástroje, jako je bagatelizace úkolu. Zvláště lidé, kterým záleží na dobrém výkonu, mohou snižovat validitu úkolu (např. úkol není formulován dobře či kritéria nejsou férová) nebo jeho celkový význam (např. úkol není důležitý, nevypovídá o schopnostech), aby pro ně př́padný neúspěch nebyl identitně závažný (Keller, 2007).

Tyto osoby se také mohou v rámci obrany vlastního já distancovat od skupiny, do niž náleží, ale vůči níž je uplatňován negativní stereotyp. Pokud se nelze zcela ze skupiny vymanit, může jedinec přistoupit $k$ tzv. bifurkaci identity. $V$ tom př́padě dojde k odmítání charakteristik skupiny, které jsou nejsilněji asociované se selháním, zatímco k ostatním charakteristikám se jedinec i nadále hlásí. Projevem je pak rozdvojení neboli bifurkace, v němž člověk zdůrazňuje „neohroženou“ část své identity nad tou, která je stereotypem znehodnocena (Flick, 1998). Nutně tím ovšem nastává redukce sociální identity, která se váže na skupinu, a tím i pokles efektivity učení probíhajícího $v$ př́tomnosti druhých.

Vedle výše popsaných důsledků efektu ohrožení stereotypem, které lze hodnotit jako negativní, může výjimečně nastat i opačný vývoj - výkonnost se může zvýšit. ${ }^{14}$ Děje se tak obvykle $v$ situaci, kdy daný člověk mívá tradičně excelentní výkony a považuje sám sebe $v$ dané oblasti za schopného. $V$ tom př́padě stereotyp vyvolá nesouhlas a snahu dokázat, že je neplatný. $U$ dobře osvojených úkolů a v konstelaci, kdy je stereotyp prezentován druhými lidmi, kteří sledují výkon, může dojít k maximalizaci výkonu pod vlivem tradičního efektu sociální facilitace (Zajonc, 1965). Jak ovšem bylo uvedeno výše, pokud úsilí překročí určitou míru, může naopak vést ke snižení výkonu.

Zcela jinou reakci na ohrožení stereotypem představuje tzv. ironický účinek, který se projevuje na výkonech stereotypem zvýhodňované skupiny. Pokud je výko-

14 Výkony mohou být zvýšeny také pod vlivem pozitivních stereotypů. C. Steele (1997) např́íklad dokázal, že na základě stereotypu, že asijští studující mají dobré dispozice pro matematiku, nastalo reálné zlepšení jejich výkonů. Protože je tento text primárně zaměřen na školní selhávání a protože většina stereotypů je negativních, ponecháváme tento důsledek efektu ohrožení stereotypem stranou. 
nová situace explicitně spojena se stereotypem a z něho plynoucími nerovnostmi, které jsou však ve společnosti považovány za nepatřičné, mohou se lidé náležející do preferované skupiny cítit nepř́ijemně. Nesouhlasí-li se stereotypem, vědomě, či nevědomě se brání dosáhnout úspěšného výsledku, aby stereotyp nepotvrdili (Průcha, 2004).

\subsection{Kritika konceptu ohrožení stereotypem}

Ačkoliv patřilo ohrožení stereotypem v uplynulé dekádě mezi nejvíce využívaná výkladová schémata školního selhávání, setkávalo se rovněž s četnou kritikou. Nejčastěji diskutované výhrady se týkaly metodologických omezení, která snižují celkovou spolehlivost výzkumů. Šetření byla realizována zejména na vysokoškolských studujících, avšak následně docházelo k zobecňování na celou populaci. Podobně bylo za chybné považováno, že výkonové situace se týkaly převážně řešení didaktických testů, které představují specifický podnětový materiál, ovšem nálezy byly interpretovány šíře než pouze jako typ úzkosti v testové situaci. Jako významné bylo viděno také kulturní omezení, nebot' použité didaktické testy byly součástí národních srovnávacích zkoušek, které představují unikátní americký fenomén, pro něž nelze ve většině jiných školských systémů nalézt paralelu. $Z$ těchto připomínek plyne, že přinejmenším první vlna experimentů neposkytovala empirickou evidenci dovolující přenos zjištění do jiných situačních kontextů (např. ústní individuální zkoušení, skupinové řešení úkolu před autoritou či bez její prrítomnosti, neakademické prostředí aj.) a jinou než vysokoškolskou populaci.

Druhá skupina kritických připomínek se vztahuje k postupům uplatňovaným při porovnávání výsledků jednotlivých skupin. Protože podnětovým materiálem byly celé národní testy či jejich části, muselo se při zpracování výsledků vycházet z procedur, které jsou v tomto národním testování upřednostňovány. Například bylo nutné vyvažovat testová skóre porovnávaných skupin, což následně zamlžuje interpretaci výsledků (Sackett, Hardison \& Culen, 2004).

Další kritika směřovala k tomu, že koncept nedokáže odlišit ohrožení stereotypem a skutečnou diskriminaci. Ohrožení vzniká na základě očekávání, že člověk mưže být znevýhodněn, což ale neznamená, že skutečně znevýhodněn je. Nedostatkem konceptu tedy byla neschopnost rozlišit, kdy se studující obávají toho, že svým výkonem potvrdí stereotyp, a kdy jsou skutečně prostřednictvím stereotypu diskriminováni. Přitom odlišení toho, zda obava vyplývá z faktů či z fantazijních představ, je nutnou podmínkou pro vnitřní validitu výzkumných nástrojů (Whaley, 1998).

Popsané tři skupiny výhrad nejsilněji zaznívaly vưči první vlně experimentů. Pozdější výzkumy se již snažily kritiku zohlednit a hlavních nedostatků se vyvarovat. Zhruba $v$ posledních deseti letech se výzkumy pokoušejí ověřit platnost konceptu ohrožení stereotypem na mladších věkových kategoriích, na jiných než akademických výkonech a v jiných než testových situacích (Schmader, Johns \& Forbes, 2008; Keller, 2007), čímž vzniká platforma pro eventuální redefinici konceptu (ve smyslu jeho zúžení, resp. zpřesnění). V aktuálních výzkumech jsou při zpracování výsledků 
24 užívány méně problematické statistické procedury (Gallagher \& Kaufman, 2004) a stále častěji se zařazují rovněž kvalitativní postupy (Doan, 2008), které dovolují mimo jiné akcentovat při výkonu vliv subjektivní percepce situace a vliv vnějších podmínek. Potvrzuje se, že ohrožení stereotypem se jako jeden z faktorů podílí na snižování výkonnosti v akademických i neakademických doménách.

\section{Závěr}

Cílem článku bylo představit koncept ohrožení stereotypem, a podpořit tak jeho integraci do české sociálněvědní diskuse o vzdělávacích nerovnostech a školní neúspěšnosti. $V$ ní dosud problematika stereotypů, které na neuvědomované úrovni vstupují do pedagogického procesu jak ze strany vyučujících, tak ze strany žáků/yň, stojí mírně v pozadí. 0 jejich negativním vlivu sice není pochyb, ale ke zmapování přesného mechanismu, kterými stereotypy žákovskou výkonnost ovlivňují, dosud nedošlo (Štech, 2000). Stereotypy v důsledku generalizování určitých charakteristik na skupinu vedou $\mathrm{k}$ přehližení individuálních dispozic jednotlivých žáků a žákyní. Tendence ke stereotypizaci je přitom velmi silná u vyučujících i u studujících - obě strany si jejím prostřednictvím pomáhají k lepší orientaci v realitě, která se však následně stává často zkreslenou a pro některé jedince/skupiny znevýhodňující. Zvědomění a odstranění stereotypů je proto základní podmínkou pro dosažení spravedlnosti ve vzdělávání (Greger, 2010).

Vliv fenoménu ohrožení stereotypem ve výkonových situacích byl v zahraničí během uplynulých patnácti let prokázán prostřednictvím velkého množství studií. Ty jsou považovány za dostatečně validní a početné, aby vynesly koncept stereotype threat do popředí odborné diskuse. Zároveň však mají své oponenty, kteří považují za diskutabilní jak metodologii, tak interpretaci výsledků zejména ve starších výzkumech, nebot' ty pracovaly výhradně $s$ daty z národních srovnávacích testů a využívaly důsledně experimentální design vzdálený běžným školním podmínkám, z čehož vyplývá (zamlčované) omezení výzkumných nálezů (Whaley, 1998; Sackett, Hardison \& Culen, 2004). Napětí mezi rychle přibývajícími studiemi a jejich kritickou oponenturou není třeba chápat jako bazální zpochybnění samotného fenoménu, nýbrž jako prostor pro další výzkumné ověřování. $K$ němu by mělo dojít i v jiném než americkém prostředí, kde se dosud realizovala většina šetření.

$\mathrm{Na}$ základě amerických výsledků nelze automaticky předpokládat jeho platnost u českých žáků/yní. Existence efektu ohrožení stereotypem je totiž podmíněna tím, že v konkrétním kulturním prostředí jsou rozšîreny specifické stereotypy dotýkající se schopností spojených s akademickými výkony. Pro českou společnost se nabízí uvažovat o stereotypech týkajících se obecné školní neúspěšnosti romských dětí, neúspěšnosti dívek $v$ technických doménách a úspěšnosti vietnamských dětí v matematice, prípadně dalších. Otázka, zda takové stereotypy jsou studujícími (a vyučujícími) v českých školách sdíleny a následně zda intervenuji do jejich výkonů, dosud čeká na podrobné prozkoumání. Prvním př́spěvkem zřejmě budou výsledky právě 
probíhajících experimentálních studií, které ověřují existenci a dopad genderových

stereotypů na školní výkonnost v matematice, tj. zda a nakolik se liší výsledky dívek a chlapců v matematických úkolech při aktivaci představy, že dívky „nemají na matiku hlavu“.

\section{Literatura}

Bandura, A. (1997). Self-efficacy: The exercise of control. New York: W. H. Freeman.

Bernstein, B. (1977). Class, Code and Control. London: Routledge \& Kegan Paul.

Bittnerová, D., Doubek, D., \& Levínská, M. (2012). Funkce kulturních modelů ve vzdělávání. Praha: Fakulta humanitních studií Univerzity Karlovy v Praze.

Blau, P. M., \& Duncan, O. D. (1967). The American Occupational Structure. New York: Wiley. Bourdieu, P. (1998). Teorie jednání. Praha: Karolinum.

Doan, L. A. (2008). A qualitative investigation of stereotype threat activation and mediation. London: ProQuest.

Flick, U. (Ed.) (1998). The psychology of the social. Cambridge: Cambridge University Press.

Franěk, M. (2009). Priming aktivující sociální stereotypy a výkon v mentálním testu. E-Psychologie, 3, 2.

Fráňová, L., \& Preiss, M. (2008). Školní známky ve vztahu k depresivní symptomatice, inteligenci a neuropsychologickým promněnným. Československá psychologie, 52(4), 321-337.

Gallagher, A. M., \& Kaufman, J. C. (2004). Gender Differences in Mathematics. An Integrative Psychological Approach. New York: Cambridge University Press.

Greger, D. (2010). Nerovnosti ve vzdělávání - od konceptů k měření. In Matějů, P., Straková, J., \& Veselý, A. (Eds.) Nerovnosti ve vzdělávání. Od měření k řešení. (s. 22-37). Praha: Slon.

Herrnstein, R. J., \& Murray, Ch. (1994). The Bell Curve: Intelligence and Class Structure in American Life. New York: Free Press.

Hnilica, K. (2010). Stereotypy, předsudky, diskriminace (pojmy, měření, teorie). Praha: Karolinum.

Hříbková, L. (2005). Nadání a nadaní. Praha: Pedagogická fakulta Univerzity Karlovy.

Jones, E. E. (1990). Interpersonal perception. New York: Macmillan.

Katrňák, T. (2005). Trídní analýza a sociální mobilita. Brno: Centrum pro studium demokracie a kultury.

Katz, I., Roberts, S. O., \& Robinson, J. M. (1965). Effects of task difficulty, race of administrator, and instructions on digit-symbol performance of Negroes. Journal of Personality and Social Psychology, 2, 53-59.

Keller, J. (2007). Stereotype threat in classroom settings: The interactive effect of domain identification, task difficulty and stereotype threat on female students' maths performance. British Journal of Educational Psychology, 77(2), 323-338.

Kohn, M. L. (1977). Class and Conformity: A Study in Values. With Reassessment. Chicago: The University of Chicago Press.

Kulhánková, E., \& Málková, G. (2008). Fonematické uvědomování a jeho role ve vývoji

gramotnosti. E-psychologie [online], 2(4), 24-37.

Lareau, A. (1992). Home Advantage. Social Class and Parental Intervention in Elementary Education. New York: Rowman \& Littlefield Publishers.

Madarasová-Gecková, A., Tavel, P., Gajdošová, B., Orosová, O., Žežula, I., \& van Dijk, J. P. (2008). Socioekonomické a psychosociálne faktory zmyslu pre integritu u adolescentov. Československá psychologie, 52(2), 132-144.

Matějů, P., Straková, J. \& Veselý, A. (eds.) (2010). Nerovnosti ve vzdělávání. Od měření k řešení. Praha: Slon.

Merton, R. K. (1968). Social Theory and Social Structure. New York: Free Press. 
26 Ogbu, J. U. (1992). Understanding cultural diversity and learning. Educational Researcher, 21(8), 5-14.

Osborne, J. W. (2007). Linking Stereotype Threat and Anxiety. Educational Psychology, 27(1), 135-154.

Pavelková, I. (2002). Motivace žáků k učení. Perspektivní orientace a časový faktor v žákovské motivaci. Praha: Pedagogická fakulta Univerzity Karlovy.

Průcha, J. (2004). Interkulturní psychologie. Praha: Portál.

Sackett, P. R. \& Hardison, Ch. M. \& Culen, M. J. (2004). On Interpreting Stereotype Threat as Accounting for African American-White Differences on Cognitive Tests. American Psychologist, 59(1), 7-13.

Simonová, N., \& Katrňák, T. (2008). Empirické přístupy v sociálně stratifikačním výzkumu vzdělanostních nerovností. Sociologický časopis, 44(4), 725-743.

Singly, F. (1999). Sociologie současné rodiny. Praha: Portál.

Schmader, T., Johns, M., \& Forbes, C. (2008). An integrated process model of stereotype threat effects on performance. Psychological Review, 115, 336-356.

Schmader, T., \& Johns, M. (2003). Converging evidence that stereotype threat reduces working memory capacity. Journal of Personality and Social Psychology, 85, 440-452.

Schneider, D. J. (2004). The psychology of stereotyping. New York: Guilford Press.

Steele, C. M., \& Aronson, J. (1995). Stereotype Threat and the Intellectual Test Performance of African Americans. Journal of Personality and Social Psychology, 69(5), 797-811.

Steele, C. M. (1997). A Threat in the Air. American Psychologist, 52(6), 613-629.

Štech, S. (2000). Sociálně kulturní pojetí handicapu. In Vágnerová, M. a kol. Psychologie handicapu. Praha: Karolinum.

Thayer, R. E. (1978). Toward a psychological theory of multidimensional activation (arousal). Motivation and Emotion, 2(1), 1-34.

Výrost, I., \& Slaměník, J. (2008). Sociální psychologie. Praha: Grada.

Whaley, A. L. (1998). Issues of Validity in Empirical Tests of Stereotype Threat Theory. Journal of Psychology, 132, 317-27.

Willis, P. (1977). Learning to Labour: How Working Class Kids Get Working Class Jobs. Farnborough: Saxon House.

Zajonc, R. B. (1965). Social facilitation. Science, New Series, 149(3681), 269-274.

PhDr. Irena Smetáčková, Ph.D., Katedra psychologie, Pedagogická fakulta, Univerzita Karlova v Praze irena.smetackova@pedf.cuni.cz 